\title{
Rapid communications
}

\section{LOW COVERAGE OF SEASONAL INFLUENZA VACCINATION IN THE ELDERLY IN MANY EUROPEAN COUNTRIES}

\author{
Jolita Mereckiene (jolita.mereckiene@hse.ie)1,2, S Cotter ${ }^{1,2}$, J T Weber ${ }^{3,4}$, A Nicoll ${ }^{3}$, Daniel Lévy- Bruhl ${ }^{5,2}$, A Ferro ${ }^{6,2}$,

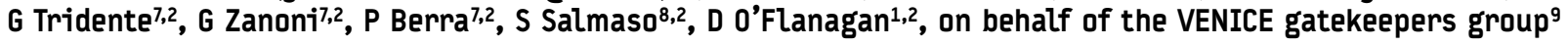 \\ 1. Health Protection Surveillance Centre, Dublin, Ireland \\ 2. Vaccine European New Integrated Collaboration Effort (VENICE) Project \\ 3. European Centre for Disease Prevention and Control, Stockholm, Sweden \\ 4. Centers for Disease Control and Prevention (CDC), Atlanta, United States \\ 5. Institut de Veille Sanitare, Saint-Maurice, France \\ 6. Department of Prevention, Public Health Unit nr 17, Veneto Region, Italy \\ 7. The Green Channel Regional Reference Centre for Vaccination, Veneto, Italy \\ 8. Istituto Superiore di Sanitá, Rome, Italy \\ 9. List of gatekeepers is available on VENICE website (http://venice.cineca.org)
}

In May 2003, the 56th World Health Assembly (WHA) recommended influenza vaccination for all people at high risk defined as the elderly and persons with underlying diseases [1]. The WHA countries, including all European Union (EU) Member States, also committed to the goal of attaining vaccination coverage of the elderly population of at least $50 \%$ by 2006 and $75 \%$ by 2010 and to having mechanisms for monitoring the uptake [1]. To date there has been no published survey on how successful European countries have been in implementing this WHA resolution.

According to the Statistical Office of the European Communities (Eurostat), 84.6 million EU citizens, $17.1 \%$ of the EU population, are currently aged 65 years or older. It is estimated that by 2010 as many as 86.7 million people will be in this age group. If EU countries are to achieve the $75 \%$ vaccination coverage rate, this will correspond to vaccinating approximately 65 million people [2].

The Vaccine European New Integrated Collaboration Effort (VENICE, http://venice.cineca.org/) project was launched in January 2006. Funded by the European Commission and supported by the EU Member States and the European Centre for Disease Prevention and Control (ECDC) it has established a network of experts who work with national immunisation programmes as national 'gatekeepers' in every EU country plus Iceland and Norway. The project carries out several activities, including performing surveys and undertaking scientific research in the field of public health regarding vaccination policies and performance for a number of infections [3] .

In late 2007 at the request of ECDC the project members undertook a survey of national influenza immunisation programmes, policies and performance in Europe. This was a collaborative study between the ECDC, the VENICE project and the EU and European Economic Area (EEA) countries. Each country had previously identified and enrolled gatekeepers responsible for conducting all VENICE surveys internally within the countries and for liaising with the ministries of health. Data presented in this paper is released ahead of the main reports because the results are relevant to the annual vaccination campaigns in Europe which are presently underway ahead of the 2008-9 winter epidemics with elderly people being the largest target group.*

\section{Methods}

A standardised questionnaire was used to collect information describing seasonal influenza vaccination policies and performance during the 2006-7 influenza season in Europe. The various objectives of the study, the methods and the results are described in detail in an article submitted to Eurosurveillance and in a formal report to be published on the website of the European surveillance network for vigilance against viral resistance (VIRGIL) [4,5]. Some of the data items were collected to obtain the most recent estimates of the levels of seasonal influenza immunisation among the elderly.

F I G U R E 1

Vaccination coverage for seasonal influenza vaccine in the elderly (65 years and older) in EU and EEA countries, season 2006-2007 (data from VENICE survey and other sources, as of March 2008)

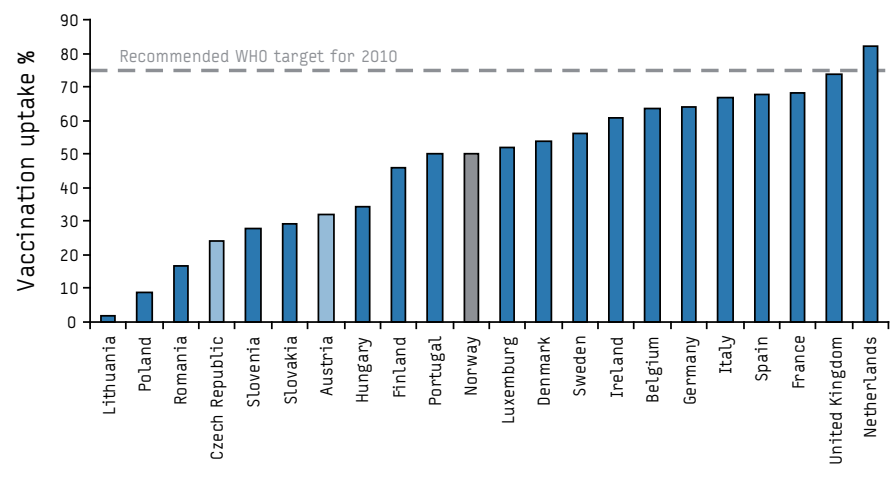

Vaccination coverage estimated through telephone surveys (University of Zurich)

$\square$ From pandemic preparedness report (2007)

Data not available for: Bulgaria,Cyprus, Estonia, Greece, Iceland, Latvia, Malta 
Data were obtained from national sources as made available by the national gatekeepers. Each country then validated the results and ensured that the ministries of health were aware of the overall results by sending them the full report [5].

\section{Results}

Data on influenza vaccine uptake in the elderly were available for 19 countries out of the 29 members of VENICE. The remaining 10 countries reported that they had not collected such data. For seven of these countries, Bulgaria, Cyprus, Estonia, Greece, Iceland, Latvia and Malta, no other sources of data were available. For two, Austria and the Czech Republic, data could be obtained from telephone surveys conducted by the University of Zurich [6]. For Norway data were available from a published national pandemic preparedness self-assessment undertaken with ECDC [7]. As a result, data on immunisation coverage in the elderly were available for 22 European countries (Figure 1).

Only one country, the Netherlands, reached the WHA 2010 target of $75 \%$ coverage in the elderly and another, the United Kingdom, was just below this target at $74 \%$. Further nine countries met the 2006 target of $50 \%$. However, the remaining eleven countries (half of those for which data were available) failed to pass the 2006 target of $50 \%$ coverage in 2006-7. A number of countries are doing especially poorly, many of them countries that joined the European Union more recently.

\section{Discussion}

The results show that the likelihood that an elderly European citizen is immunised against influenza is related to his or her country of residence.

The reasons for such wide variations in vaccination uptake are not clear. This information was not sought in our study. Further research is needed to determine underlying reasons.

Comparison with an earlier published survey with data from 2000-2001 shows encouraging increases for seven countries over the six years (Figure 2). However it has been suggested that as countries reach higher levels the total rates plateau at or below

\section{F I G U R E 2}

Reported influenza vaccination uptake among the elderly in nine European Union countries, survey results for seasons 2000-1 (Nivel) and 2006-7 (VENICE/ECDC)

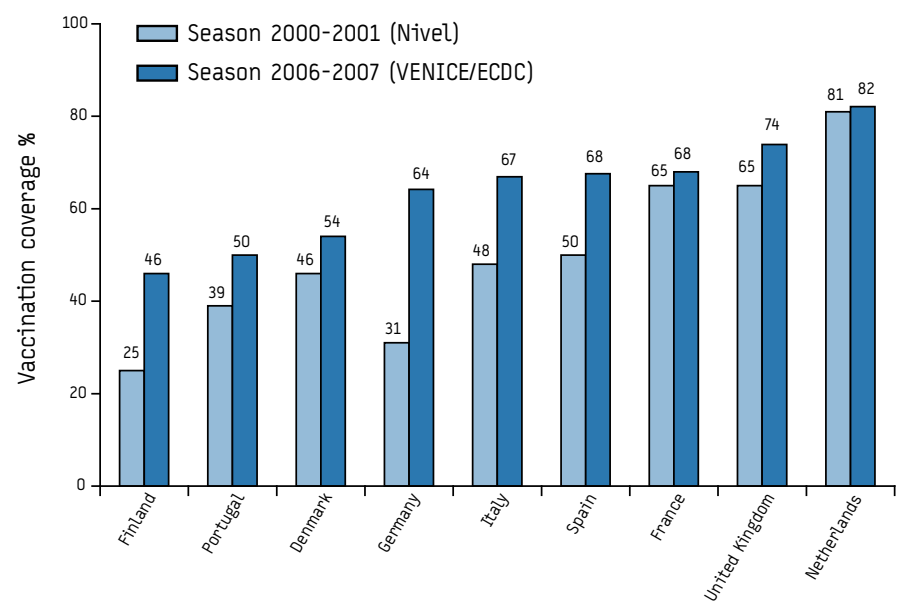

$75 \%$ [8]. This suggestion is supported by the telephone surveys conducted by the University of Zurich using the same methodology for six seasons and five countries: France, Germany, Italy, Spain and the UK [6].

Comparison of our data for 2006-7 with the figures for North America where the United States (US) coverage in the elderly for the same season was estimated to be $65.6 \%$ [9] indicates that while some European countries are doing better than the US, Europe as a whole is lagging behind.

It should also be recalled that the $75 \%$ target is entirely arbitrary. The immunisation strategy for preventing human seasonal influenza aims at protecting vulnerable individuals rather than trying to achieve herd immunity and reduce transmission in the community [10]. Some groups are more likely to develop severe disease and die as a result of influenza infection and ECDC estimates that at least 40,000 deaths in Europe annually, many of these in the elderly, are attributable directly or indirectly to influenza [11]. With that in mind the only real target for risk groups should be at or approaching $100 \%$. It is of equal concern that while in 2000-1 season, 14 out of 23 European countries could monitor the coverage in the elderly, six years later this number had only increased to 19 out of 29 . The fact that ten European countries still do not have any system in place with which to estimate uptake in this high risk group is worrying and suggests that Europe will struggle to achieve the WHA target for 2010 or even to produce good statistics for all its countries.

\section{Acknowledgments}

We would like to acknowledge all VENICE gatekeepers and contact points who contributed to conducting this study, and Patricia Blank, Thomas Szucs and Matthias Schwenkglenks and the Universities of Zurich and Basel for permission to use their data in Figure 1.

*Editors' note: Eurosurveillance has agreed with the authors to publish the data in this rapid communication ahead of a later full-length article covering the study in greater detail, recognising the public health need to have this information in the public domain in the beginning of the annual influenza immunisation season. We believe that this decision conforms to the principles of secondary publications as agreed by the International Committee of Medical Journal Editors (http://www.icmje. org/index.html).

\section{References}

1. World Health Organization. Resolution of the World Health Assembly (WHA 56.19). Prevention and control of influenza pandemics and annual epidemics. WHA 10th plenary meeting. 28-5-2003. Ref Type: Bill/Resolution

2. Statistical Office of the European Communities (Eurostat). Ageing characterises the demographic perspectives of the European societies. 26 August 2008. Eurostat. Statistics in focus. Issue 72/2008. Available from: http://epp.eurostat. ec.europa.eu/cache/ITY_OFFPUB/KS-SF-08-072/EN/KS-SF-08-072-EN.PDF

3. Pastore Celentano L, Lopalco PL, O’Flanagan D, Lévy-Bruhl D, Ferro A, Tridente $G$ et al. VENICE: Europe's new network for vaccination. Euro Surveill. 2007;12(3):pii=3116. Available from: http://www.eurosurveillance.org/ ViewArticle.aspx?ArticleId=3116

4. Mereckiene J, Cotter S, Weber JT, Nicoll A, Levy-Bruhl A, Ferro A, et al. National Seasonal Influenza Vaccination Survey in Europe, 2007. Eurosurveillance 2008 (forthcoming)

5. VENICE Influenza immunisation survey full report (forthcoming on the websites of VIRGIL: http://www.virgil-net.org/ and VENICE: http://venice.cineca.org/)

6. Blank P.R. Schwenkglenks M, Szucs TD. Influenza vaccination coverage rates in five European countries during season 2006/07 and trends over six consecutive seasons. BMC Public Health. 2008;8:272. 
7. Norwegian Ministry of Health and Care Services. Rapport fra felles gjennomgang av norsk beredskap mot pandemisk influensa 2007. Available from: http://www.regjeringen.no/nb/dep/hod/tema/folkehelse/rapport-frafelles-gjennomgang-av-norsk-.html?id=509944

8. Kroneman M, Paget WJ, van Essen GA. Influenza vaccination in Europe: an inventory of strategies to reach target populations and optimise vaccination uptake. Euro Surveill. 2003;8(6):pij=418. Available from: http://www. eurosurveillance.org/ViewArticle.aspx?ArticleId $=418$

9. United States Centers for Disease Prevention and Control. Influenza Vaccination Coverage Levels Results for 2006-7 Season. Available from: http://www.cdc. gov/flu/professionals/acip/coveragelevels.htm

10. Couch RB. Seasonal inactivated influenza virus vaccines. Vaccine 2008;26(Supplement 4):D5-D9.

11. European Centre for Disease Prevention and Control. Seasonal Human Influenza and Vaccination - the Facts. Available from: http://ecdc.europa.eu/pdf/071203 seasonal_influenza_vaccination.pdf

This article was published on 9 October 2008.

Citation style for this article: Mereckiene J, Cotter S, Weber JT, Nicoll A, Lévy-Bruhl D, Ferro A, Tridente G, Zanoni G, Berra P, Salmaso S, O'Flanagan D, on behalf of the VENIC gatekeepers group. Low coverage of seasonal influenza vaccination in the elderly in many European countries . Euro Surveill. 2008;13(41):pii=19001. Available online: http:// www.eurosurveillance.org/ViewArticle.aspx?ArticleId=19001 